Tér és Társadalom 22. évf. 2008/4. 229-234. p.

Tér és Társadalom

XXII. évf. 2008

4: $229-243$

\title{
KÖNYVJELZÖ
}

\section{KIRIL STANILOV (ED.): THE POST-SOCIALIST CITY}

(Springer, Dordrecht, 2007. 490 o.)

\section{ENYEDI GYÖRGY}

A Wolf Tietze által alapított, értékes publikációkban bővelkedő Geo Journal Libray 92. kötete a poszt-szocialista városról - a kelet- és közép-európai korábbi szocialista országok városainak müködéséről, városi terének, épített környezetének átalakulásáról szól. Bevallom, nem nagyon kedvelem a poszt-szocialista megnevezést - meddig tart még a tranzitológia? Meddig neveznek még minket ,poszt"-nak? Eszébe jutott-e valakinek 18 évvel Franco tábornok diktatúrájának bukása után Spanyolországot poszt-fasisztának nevezni? Pedig a diktatúrából a demokratikus intézményrendszerekre való áttérés Spanyolországban lassabban s jobban akadozva ment végbe, mint Közép-Európában. A kelet- és közép-európai országok intézményrendszere teljesen megfelel a parlamenti demokrácia és a piacgazdaság szabályainak. Politikai és közgazdasági szempontból is értelmetlen a hidegháború abszurd geográfiáját, - amely szerint Prága keleten volt és Athén nyugaton - továbbra is emlegetni.

Városokról szólván azonban a poszt-szocialista megkülönböztetés még indokolt lehet. Kelet- és Közép-Európa városai még magukon viselik az államszocialista rendszer formai jegyeit - az épített környezet pedig a városi társadalom múködését is befolyásolja. A térség országainak általános, a teljes településhálózatot átalakító modern urbanizációja - a korán városiasodott Csehország és talán Szlovénia kivételével - az államszocialista rendszerben teljesedett ki. Mind az ipari, mind a posztindusztriális városhálózat egésze a szocialista rendszer (ezzel a központi tervezés és az állami tulajdon) terméke. Néhány jelentős nagyváros - mint Budapest, Bukarest, Varsó, Krakkó - és néhány hagyományos ipari központ mellett a városhálózat zömét az ipar előtti városokra jellemző szolgáltató, kereskedő, közigazgatási, vásárhely városok alkották. A 20 . század második felének városa az államszocializmus terméke. A visszatérés a korábbi urbanizációs folyamatokhoz, a régebbi történelmi trendek folytatása hosszú időt vesz igénybe.

Másik fontos tényezô, - melyet a kötet nem vizsgál -, a városi társadalom sajátos szerkezete: a városi polgár hiánya. A független, tulajdonnal rendelkezö, a várost felelősen irányító polgárságot a II. világháború, a náci koncentrációs táborok, a háború utáni kitelepítések, majd a kommunista rendszer eröszakos uralomra jutása eltüntették. A polgári középosztály újjáalakulása, a városi polgári magatartási minta 
elterjedése lassú, generációs léptékủ időfolyamat - úgy tủnik ehhez az elmúlt 19 év még rövid idő volt.

Stanilov valóban alkotó szerkesztő volt: gyakorlatilag egy öt fejezetből álló összefoglaló müvet írt a témáról, majd az egyes fejezetekhez invitált szerzőket, akik esettanulmányokat mutattak be. A 23 tanulmányból hétnek Stanilov a szerzője. A szerkesztő arra törekedett, hogy érzékeltesse a vizsgált régiók sokszínủségét, a posztszocialista jelző nem egy homogén városcsoportra vonatkozik. Nem sorolja külön urbanizációs típusba Közép- és Kelet-Európát, inkább azt sugallja, hogy minden város külön eset, ill. alapvonásait tekintve mindegyik poszt-szocialista város hasonló a központi tervezés szétesésében, a kaotikus nyugat utánzó (inkább az Egyesült Államokat, mint Nyugat-Európát utánzó) jelenlegi városépítésben (pl. a bevásárlóközpontok uralma), a tömeges lakásprivatizációban stb. A kelet- és a közép-európai urbanizációs tájak markánsabb szétválasztása azonban indokolt lett volna, hiszen az átmenet első fázisa lezárulván, a jelen időszak lassan újraszületô szabályozási, várostervezési felfogásában, a városi térhasználati szokásokban újra felszínre kerülnek a szocializmus elötti periódus eltemetett, de nem elfeledett, újjáéledő elemei, amelyek a Balkán, Kelet-Európa és Közép-Európa városaiban ugyancsak eltérőek voltak. Viszszatérnek a hosszú távú trendek - és ma is kinyomozható a városi innovációk Nyugatról Keletre való terjedési folyamata.

A könyv 6 részre oszlik. Ezek: a poszt-szocialista városfejlödés jelen helyzetét összefoglaló bevezetés; a regionális fejlődési trendek; a nem-lakás célú építések; a lakó övezetek átalakulása; a közterek fejlődése $s$ végül a jelenlegi várospolitika és várostervezés jellemzése.

Az esettanulmányok többsége a legfontosabb nagyvárosok példáján keresztül mutatja be az átalakulást. Ezek három kivétellel EU-tagállamok fóvárosai, intézményesen tehát integrálódtak az európai városrendszerbe. Az egyik kivétel Oroszország, mely az átmenet módját és a rendszerváltás utáni pálya építését tekintve is külön utat jár (a modern urbanizáció kezdetétől); a másik pedig Belgrád - ne feledjük, hogy a mély válságban vergődő Szerbia is része a poszt-szocialista világnak. (A harmadik kivétel, Zágráb, nem különbözik EU-tag szomszédaitól).

A városfejlődés belehelyezése a regionális fejlődés általános trendjébe jó koncepció; a szerkesztő bevezetője kitűnö, a térség egészének alapos ismeretét tükröző jellemzése a gazdaság néhány éven belüli drasztikus átalakulásának és területi következményeinek. Jeffrey Sachs sokk terápiáját, - melyet csak Lengyelországban alkalmaztak - Ö sem szereti, „több sokkot okozott, mint amennyi terápiát adott” írja, de a sokk elkerülhetetlen volt. Hazánkban a bruttó hazai termék 1990 és 1993 között nagyobb mértékben esett vissza, mint 1938 és 1946 között, tehát a II. világháború alatt! (Így utólag csak bámulhatjuk a társadalom alkalmazkodó és túröképességét - a későbbi gyors fellendülés reményében.) Az esettanulmányok azonban halványak. A két Koloman Ivanicka (apa és fia) tanulmányának címe „A regionális növekedés dinamizmusa Kelet- és Közép-Európában" sokat ígér, de gyakorlatilag csak a szlovák regionális átalakulást jellemzi, színvonalasan; a másik esettanulmányból pedig az orosz urbanizáció változásáról kapunk vázlatos információkat. 
Tér és Társadalom 22. évf. 2008/4. 229-243. p.

A városok épített környezetében a legfontosabb változást a kereskedelmi-vállalati terek kibővülése és a lakóterületek átalakulása jelentette. Ebben nagyon különböző mechanizmusok játszottak szerepet, és jelentős különbségek mutatkoznak a régen urbanizált közép-európai fôvárosok (Budapest, Prága) és a hirtelen nagyra nőtt délkelet-európai nagyvárosok (Szófia, Belgrád) között. A nagy, előre gyártott elemekböl épített olcsó bérü köztulajdonú lakótelepek mindenütt kiterjedtek voltak az államszocializmus idején, de a régi közép-európai városokban nem játszottak nagy szerepet a városkép formálásában, a városok peremén helyezkedtek el. Az egalitáriánus társadalmak felbomlása, a társadalmi egyenlötlenségek fokozódása a lakáspiac differenciálódását - luxus lakások építését - is megkívánta. A lakásállomány privatizációjának módja sokféle volt - restitúciótól a bérlőknek való eladásig -, általában azonban nagyon nagy mértékú volt, kevés bérlakás maradt. Jelenleg a szociális bérlakás-építés minimális, mely sok társadalmi feszültség forrása a területi mobilitás korlátozásától a hajléktalanságig.

A nem-lakáshasználatú épített környezetben irodaházak és a kereskedelmi terek robbanásszerü terjedése, továbbá az ipari terek (a barnamezők) átalakítási igénye jellemző. A kereskedelmi terek bővitésének igénye gyorsan s tömegesen jelentkezett. Az igényeknek az éppen kibontakozó, gyenge hazai tőke sehol sem tudott megfelelni. Transznacionális fejlesztők beruházásaiként, gyakran városrendezési tervek megsértésével épültek kereskedelmi terek. Pl. a bevásárlóközpontok tömeges megjelenése érthetö, hiszen ugrásszerủen nőtt a fogyasztás igénye, de tönkretette a hagyományos bevásárló utcákat. Nyugat-Európa nagyvárosaiban a városrendezés nem engedte be a bevásárlóközpontokat a belsö lakóterületekbe.

A nagyvárosok hajtóereje egészen az 1980-as évekig az iparosítás volt, az ipar hirtelen összeomlása és eltủnése igen nagy barnamezős területeket hagyott üresen ezek a fövárosok belterületének akár 30-40\%-át is kiteszik. Roppant méretú átalakulás folyik; mozgatórugói több esettanulmányt érdemeltek volna: Sykora ír a hivatali építkezésekről, vázlatos képet kapunk Moszkva kereskedelmi tereiről (melyek eléggé sajátosak és nem jellemzőek a vizsgált régióra), Kiss Éva pedig Budapest barnamezős átalakulásáról ír.

Kimunkált a lakás fejezet. E témának roppant nagy a nemzetközi szakirodalma. A lakásprivatizáció formái különbözőek voltak; közös vonás azonban a lakótelepi népesség nagy aránya, az új bérlakás-építés megtorpanása, a gyors szuburbanizáció, a történelmi belvárosok hanyatlásának és dzsentrifikációval járó felújitásának szinte időbeni egymásra tolódása. Ezek hasonló jelenségek, mint amelyek Nyugat-Európa nagyvárosaiban lejátszódtak, de ott ez jóval hosszabb ideig tartott és részben eltérö volt a mechanizmusuk. A három esettanulmány közül a magyar olvasónak különösen érdekes Krok és társainak tanulmánya a lakóingatlan visszaadás (restitúció) társadalmi és térbeni következményeiről - hazánk volt az egyetlen poszt-szocialista ország, ahol (az egyházi ingatlanok részbeni visszaadásán kívül) csak pénzbeli kárpótlás volt, restitúció nem. Így nem is érzékeljük, mennyi társadalmi feszültséget okozott a restitúció - pl. ki volt az eredeti tulajdonos? Általában az 1948. évi tulajdonviszonyokat vették figyelembe, ezzel kívánták az államszocialista rendszer 
államosításának kárvallottjait kárpótolni, ám ezzel kizárták a restitúcióból a holokauszt sokmillió áldozatát, illetve az 1945-1946-ban kitelepített sokmillió német és több százezer magyar leszármazottait! (Magyarországon 1939 volt a kárpótlási időpont.)

Érdekes, ritkán vizsgált téma a közösségi terek használata, átalakulása a városokban. A közösségi tereknek nagy a szimbolikus jelentösége a városi társadalom életében. Az államszocialista rendszer is megpróbált külön saját köztereket létrehozni - a történelmi közép-európai nagyvárosok esetében szerencsére sikertelenül. Az esettanulmányok inkább kuriózumok, mintsem jellemzőek lennének (a közterek Oroszország korábbi zárt városaiban - ahová csak külön engedéllyel lehetett beutazni -, ilyenek az egész térségben sehol máshol nem fordultak elő; vagy hogyan keveredik ki Bukarest Ceaucescu megalomán hatalmi tereiböl). A Balti köztársaságok városközlekedési fejezete meg végkép érdektelen a kötet témájának szempontjából.

Az utolsó két rész a várospolitika és a várostervezés helyzetével foglalkozik. Itt is erösen és hosszabb ideig érzödik az államszocialista örökség, ami a városfejlődés minden oldalát erősen befolyásolja. Az átmenet első éveiben a piac mindenhatóságában éppen úgy bizakodtak, mint az államszocializmus idején a központi tervezésben. Nemzeti várospolitika gyakorlatilag nem létezett, a helyi építési szabályokat pedig az állampolgárok, akik a kormányzattal, a hatalommal való szembeszegülés egyik formájaként a nélkülük és olykor ellenükre alkotott szabályok kijátszásának ezer módját dolgozták ki az államszocializmus idején, ${ }^{1}$ rendszeresen és többnyire következmények nélkül megsértették. A városfejlődés, az épített környezet átalakulása így eléggé kaotikus volt. A városszerkezetben súlyos torzulásokat okozott, pl. a bevásárlóközpontok benyomulása a belvárosokba, tönkre téve a hagyományos üzlet negyedeket vagy a városi zöldterületek beépítése, egyáltalán az épített környezet alakításának szabályozatlansága. A várospolitika-várostervezés helyzete különösen ott vált kritikussá, ahol a társadalmi-politikai feszültségek súlyosak voltak, amint ezt Belgrád és Zágráb esettanulmánya illusztrálja. A várostervezők szerepe drámaian megváltozott. Kihátrált mögülük az állam (többnyire a helyi önkormányzat is), mely minden áron befektetóket, ingatlanfejlesztöket igyekezett vonzani, de nem támaszkodtak - az egyébként is gyenge - civil szervezetekre sem. A várostervezők úgy vélték, szakkérdésekbe nem szólhatnak bele a civilek, ezért a közösségi részvételt föleg a tiltakozás - a nélkülük, olykor valóban vagy csak feltételezve érdekeik ellen készített tervekkel való szembenállás - jellemzi. A kötet záró tanulmányai az új körülményekhez alkalmazkodó, az üzleti, a civil társadalmi és törvényi szabályozást egyeztető, a közjót szolgáló stratégiai várostervezést mutatják be.

Fontos, érdekes könyv. Sok szerzỏ esetén a színvonal törvényszerủen egyenetlen, és olykor az esettanulmányok szerzőinek kiválasztásában talán a véletlen nagyobb szerepet játszott, mint a céltudatos szakmai kiválasztás, de azért kevés a hiányérzetünk. A szerkesztô, Stanilov szellemi teljesítménye, a roppant sokszínủ átalakulás szintézise elismerést, továbbgondolást, tovább folytatást érdemel. 
Tér és Társadalom 22. évf. 2008/4. 229-243. p.

\section{Jegyzet}

${ }^{1}$ Ezt neveztem - a második gazdaság (tehát az ámyékba húzódott magángazdaság) mintájára „II. urbanizációnak” (Enyedi 1992).

\section{Irodalom}

Enyedi,Gy. (1992) Urbanisation in East-Central Europe: social processes and societal responses in the state socialist system. - Urban Studies. 6. 869-880. o. 
Tér és Társadalom 22. évf. 2008/4. 229-243. p.

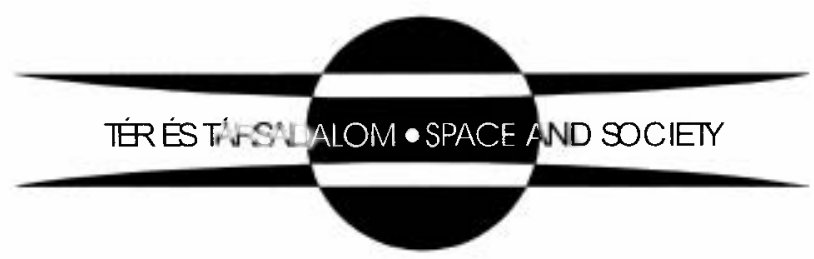

